\title{
LAMINAR NATURAL CONVECTIVE HEAT TRANSFER IN PARABOLIC ENCLOSURES
}

\author{
Ola Kamiyo \\ Department of Mechanical Engineering, University of Lagos, Lagos, Nigeria. Email: \\ okamiyo@unilag.edu.ng
}

HTTPS://DOI.ORG/10.30572/2018/KJE/120406

\begin{abstract}
A finite volume analysis of laminar natural convection of air within full parabolic enclosures heated from below is reported for the enclosure aspect ratio $0.27 \leq \mathrm{AR} \leq 0.7$ and a range of the Rayleigh number $5.5 \times 10^{6} \leq \mathrm{Ra} \leq 9.8 \times 10^{7}$. The shape of the enclosures strongly affects the results obtained. Quasi-symmetrically arranged counter-rotating vortices are formed in each of the enclosures. The shape of the cells are influenced by the bounding curved and flat surfaces as they change from being rectangular at the periphery to circular at the core. There are reduction in the size and intensity of the on the cells from the center to the bottom corners. At steady state, there exists in each enclosure a central thermal plume that thickens as the roof pitch angle increases. The heat transfer pattern matches the flow of the plumes and jets from the walls. For the $15^{\circ}$ roof pitch enclosure, the heat transfer rate increases sharply at a critical Ra value of $5 \times 10^{6}$.
\end{abstract}

KEYWORDS: Parabolic Enclosure, Natural Convection, Heat Transfer, Pitch Roof, Pitch Angle. 


\section{INTRODUCTION}

Over the years, exterior architecture of the roofs of most large buildings such as factories, warehouses, worship centres, aircraft hangars, shopping malls and indoor sport halls are mostly parabolic in nature. In the Middle East, dome or vaulted roofs are very common. Among its numerous advantages, parabolic roof easily shed off rain and snow, effectively diffuse sunrays and minimize accumulation of dirt. The interior view of roofs of parabolic shape has inimitable decorative features characterized by large space volume and aesthetic magnificence. In the extant literature, a number of researchers have reported various investigations on the parabolic roof. On the design, a number of studies were carried out. The effect of design pressure coefficients on hyperbolic paraboloid roof was examined by Rizzo and Riccardelli (2017) and Colliers et al. (2020). Rizzo et al. (2018) reported the peak factor statistics of wind effects while Shen et al. (2020) numerically studied the dynamics of the same paraboloid roof. Simoni and Nordestgaard (2017) used hyperbolic paraboloid shape shell structure as a roof for an outdoor music stage.

On the studies on airflow and heat transfer within parabolic roofs, Talabi and Nwabuko (1993) reported the laminar free convective heat transfer in a parabolic enclosure heated from above for isothermal and constant heat flux boundary conditions. In both cases, the heat transfer rate to the cold wall increases with Rayleigh number. Das and Morsi (2002) studied heat transfer within curved roofs numerically and observed that roofs with circular and elliptic shapes had higher heat transfer rate. Runsheng et al. (2003) compared the effect of absorbed solar radiation on the total solar heat gain by vaulted and flat roofs for different climate characteristics and latitude. Using a numerical technique, Varol et al. (2007) investigated the flow field and heat transfer in gambrel roofs for Rayleigh number between $10^{3}$ and $10^{7}$ under winter and summer conditions. The result shows that Nusselt number increased with Rayleigh number for both cases. Yesiloz and Aydin (2011) reported experimental and numerical natural convection and heat transfer in an inclined quadrantal cavity to investigate the effects of the inclination angle and the Rayleigh number. It was found that the inclination angle significantly affect the heat transfer. Thermal performance of domed and flat roofs was compared by Faghih and Bahador (2011). They observed that buildings with domed roof performed better than that with flat roof, especially when covered with glazed tiles.

Mustafa (2011) examined how the vertical curved walls influences the natural convection within an inverted trapezoid. The bottom and the curved vertical walls were at constant temperatures with insulated top wall. The heat transfer rate decreases inversely with the 
concavity factor associated with the curved walls. Using the Bejan's heatlines approach, Basak et al. (2013) reported natural convection in porous right angled triangular enclosures with a concave and convex hypotenuse. Haghighi et al. (2015) used vented vaulted roof to improve the thermal comfort in a building. Elnokaly, et al. (2019)_parametrically investigates the thermal performance of vaulted roofs with varying cross-section ratios and orientations in order to enhance the indoor thermal comfort of buildings in hot-arid regions.

In this study, the focus is on investigating natural convective heat transfer in full geometry of parabolic rooftops heated from the bottom wall as reported in Holtzman et al. (2000).

\section{METHODOLOGY}

A long, horizontal attic space with a parabolic cross-section shown in Fig. 1 is considered in this study. The roof extends more than double its width in length. The flow field and heat transfer are then two-dimensional (Penot and N'Dame, 1992).

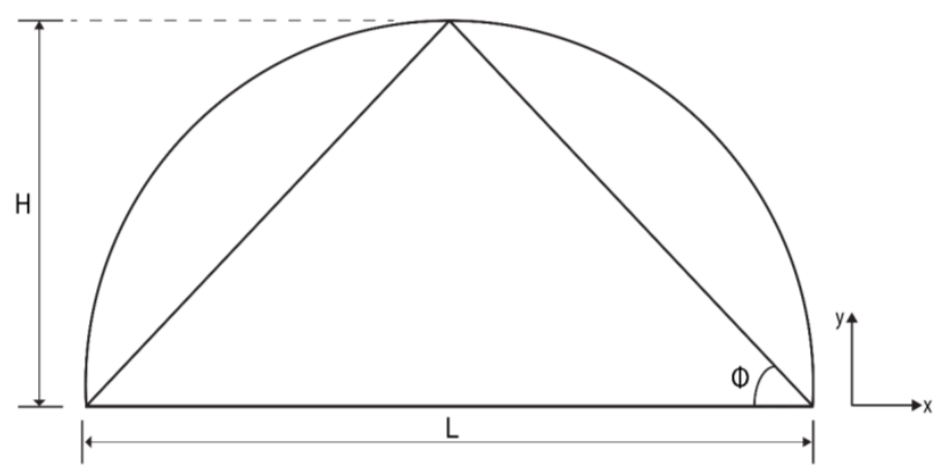

Fig. 1. Physical model

The enclosure with no internal heat generation is filled with dry air. The Boussinesq approximation is employed; Gray and Giorgini (1976) and Ridouane et al., (2005) validate this assumption.

In actual sense, the roof size depends on the building dimensions. Therefore, the boundary conditions and the dimensions of the modeled physical domain, which coincides with the computational domain, are normalized. Under steady-state conditions, the governing equations, in dimensionless forms with Boussinesq approximation, are presented as:

Conservation of Mass:

$\frac{\partial U}{\partial X}+\frac{\partial V}{\partial Y}=0$ 
Conservation of Momentum:

X-momentum

$$
U \frac{\partial U}{\partial X}+V \frac{\partial U}{\partial Y}=-\frac{\partial P}{\partial X}+\operatorname{Pr}\left(\frac{\partial^{2} U}{\partial X^{2}}+\frac{\partial^{2} U}{\partial Y^{2}}\right)
$$

Y-momentum

$$
U \frac{\partial V}{\partial X}+V \frac{\partial V}{\partial Y}=-\frac{\partial P}{\partial Y}+\operatorname{Pr}\left(\frac{\partial^{2} V}{\partial X^{2}}+\frac{\partial^{2} V}{\partial Y^{2}}\right)+\operatorname{RaPr} \theta
$$

Conservation of Energy

$$
U \frac{\partial \theta}{\partial X}+V \frac{\partial \theta}{\partial Y}=\left(\frac{\partial^{2} \theta}{\partial X^{2}}+\frac{\partial^{2} \theta}{\partial Y^{2}}\right)
$$

where $\mathrm{X}=\frac{x}{L}, Y=\frac{y}{L}, V=\frac{v L}{\alpha}, U=\frac{u L}{\alpha}, \quad \theta=\frac{T-T_{C}}{T_{H-T_{C}}}, P=\frac{p L^{2}}{\rho \alpha^{2}}, \operatorname{Pr}=\frac{v}{\alpha}, \quad$ and

$R a=\frac{g \beta\left(T_{H}-T_{C}\right) H^{3}}{\alpha \nu}$.

Boundary conditions:

On the hot horizontal base wall, $\mathrm{U}=\mathrm{V}=0 ; \theta=1$.

On the cold parabolic wall, $\mathrm{U}=\mathrm{V}=0 ; \theta=0$.

The pitch angles selected are within range for standard roofs. The parametric details are given in Table 1.

Table 1. Parametric details of the enclosures.

\begin{tabular}{rcccc}
\hline Pitch Angle $(\boldsymbol{\phi})$ & $15^{\circ}$ & $20^{\circ}$ & $25^{\circ}$ & $35^{\circ}$ \\
Aspect Ratio, $\boldsymbol{A R}$ & 0.27 & 0.36 & 0.47 & 0.70 \\
Rayleigh Number $(\boldsymbol{R a})$ & $5.5 \times 10^{6}$ & $1.39 \times 10^{7}$ & $2.91 \times 10^{7}$ & $9.86 \times 10^{7}$ \\
\hline
\end{tabular}

As shown in Fig. 2 for the $35^{\circ}$ enclosure, the computational domain is meshed with unstructured very fine mesh. ANSYS FLUENT ${ }^{\odot}(\mathrm{V}-18)$ is used to solve the governing equations numerically. The pressure-velocity coupling is handled by the SIMPLE scheme. Pressure interpolation is resolved using the PRESTO scheme. The momentum and energy equations are discretized spatially using the QUICK scheme. For the residuals of the equations, the convergence target for the conservation of mass was fixed at $10^{-5}$ and at $10^{-7}$ for the momentum and energy equations. At all the walls, no slip condition applies. 


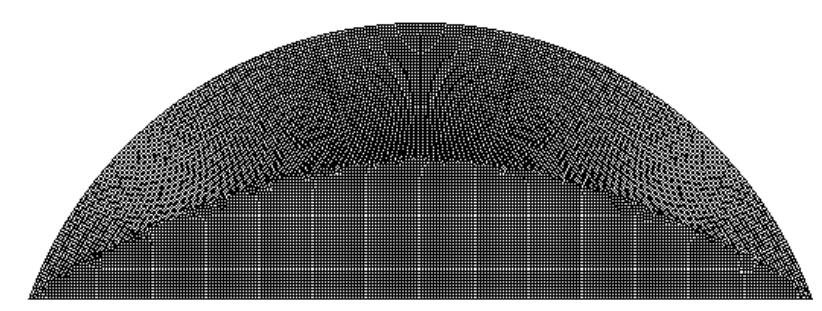

Fig. 2. Computational grid for the $35^{\circ}$ pitch enclosure.

For the accuracy of the solution scheme, grid independence tests were carried out. From Table 2 for the $15^{\circ}$ enclosure, 43,000 elements were found adequate for grid independence..

Table 2. Grid independence test for the $15^{\circ}$ enclosure.

\begin{tabular}{rlll}
\hline Number of elements & 42,666 & 54,356 & 91,796 \\
$\mathbf{U}_{\max }(\mathrm{m} / \mathrm{s})$ & 0.0288 & 0.0289 & 0.0289 \\
\hline
\end{tabular}

\section{RESULTS AND DISCUSSION}

The predicted flowfield results are presented in the form of streamlines, air velocity contour plots and air velocity variations across some cross-sections in Figs. 3-6. The isotherms and temperature variations across some cross-sections are in Figs 7-9. The heat transfer patterns are shown in form of the variations of the Nusselt number along the hotwall in Figs.10-13. The figures for all the pitch angles considered are presented together for ease of comparing in order to observe the parametric changes with the roof pitch. This will aid engineering interpretation and applications of the results for related specific conditions.

\subsection{Flowfield}

The streamlines over the range of roof pitch considered are shown in Fig. 3. Streams of hot, rarefied air rising from the hot horizontal wall in form of plumes hit the cold parabolic wall perpendicularly. It then loses a major part of its heat content and flows downhill along the curved wall. Detaching as cold jets from the curved wall, it descends to be reheated by the base wall and repeat the process. This leads to multiple counter-rotating, recirculating vortices arranged quasi-symmetrically at steady state. The size and intensity of the cells reduce from the midsection towards the corners. As the pitch angle increases, the number of the cells reduces because the cells merge. From six in the $15^{\circ}$ roof pitch enclosure, it reduces to just two in the $35^{\circ}$ pitch enclosure. The multi-cellular flow structure obtained is similar to that reported by Holtzman et al. (2000) in their flow visualization experiments in enclosures heated from the 
basewall. Due to symmetry assumption, Yesiloz and Aydin (2011) could not obtain multicellular flow pattern in the quadrant cavity studied.

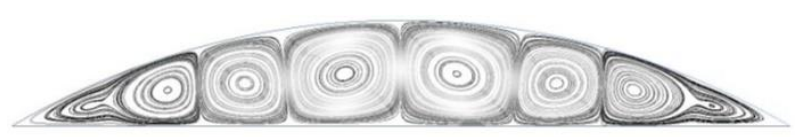

(a) $15^{\circ}$

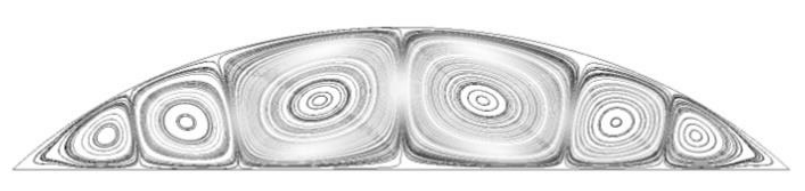

(b) $20^{\circ}$

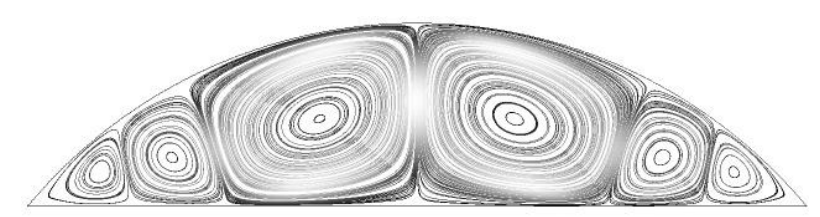

(c) $25^{\circ}$

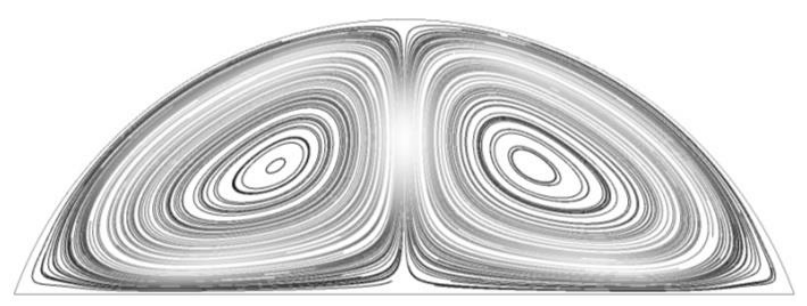

(d) $35^{\circ}$

Fig. 3. Streamlines for different roof pitch enclosures.

Unlike the circular cells formed in isosceles triangular enclosures when heated from below (Holtzman et al., 2000), the cells formed change structure from being rectangular at the periphery to circular at the core. That implies that the shapes of the cells are moulded by the bounding curved and flat surfaces. The number of cells in the $15^{\circ}, 20^{\circ}$ and $25^{\circ}$ enclosures remains somehow the same in number but as the roof pitch angle increases, the cells grow thicker. Adequate knowledge of this flow structure would guide the roof designers and also building owners in the use of the attic space. 


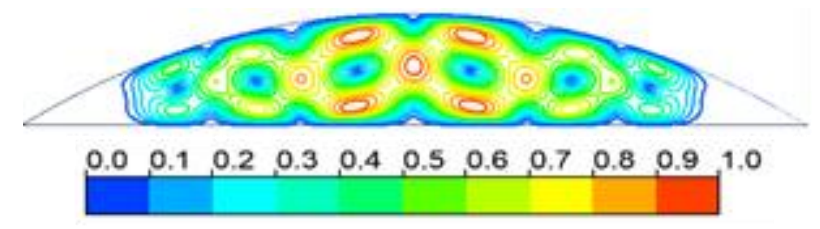

(a) $15^{\circ}$

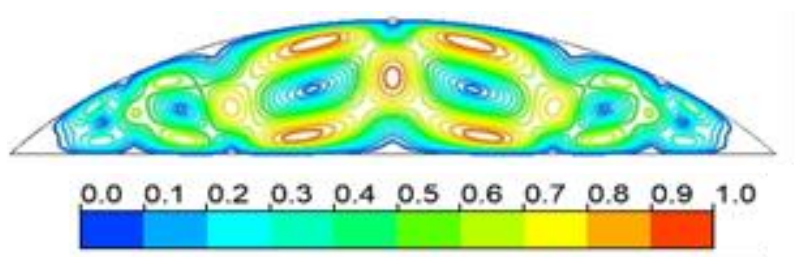

(b) $20^{\circ}$

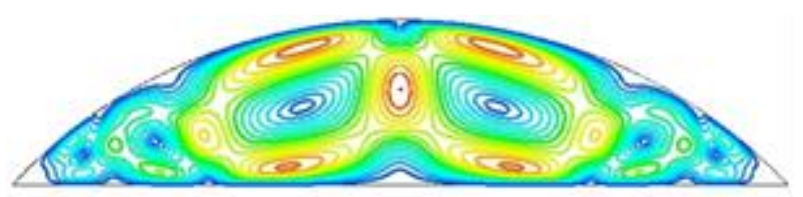

$\begin{array}{llllllllllllll}0.0 & 0.1 & 0.2 & 0.3 & 0.4 & 0.5 & 0.6 & 0.7 & 0.8 & 0.9 & 1.0\end{array}$

(c) $25^{\circ}$

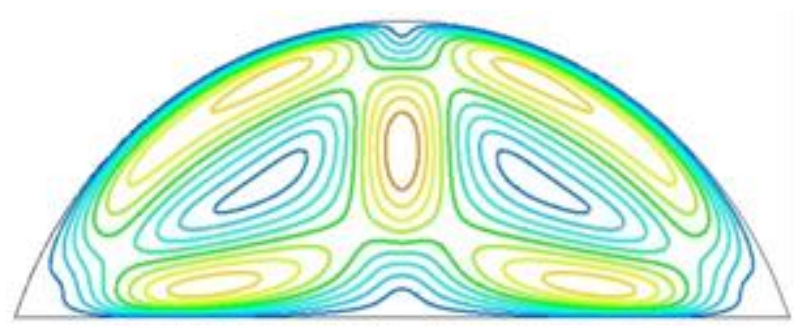

$\begin{array}{lllllllllllllllll}0.0 & 0.1 & 0.2 & 0.3 & 0.4 & 0.5 & 0.6 & 0.7 & 0.8 & 0.9 & 1.0\end{array}$

(d) $35^{\circ}$

Fig. 4. Velocity contour plot for each enclosure.

The air velocity distributions within different roof pitch enclosures are presented in Fig. 4. Velocity is highest at locations where a cell meets an adjacent cell or on the walls. Typically, across a cell, the velocity range is divided into two regions: the peripheral area where the velocity is high and the core region where the velocity is very low. Near the bottom corners, conduction dominates. This conduction area reduces as roof pitch increases. In Fig. 4(a-c), the strength of the vortices reduces from the center of the enclosure to the bottom corners. In Fig. 4 (d), due to the large area covered by each of the two high velocity vortices, the air in the $35^{\circ}$ roof pitch enclosure is more uniformly mixed. 


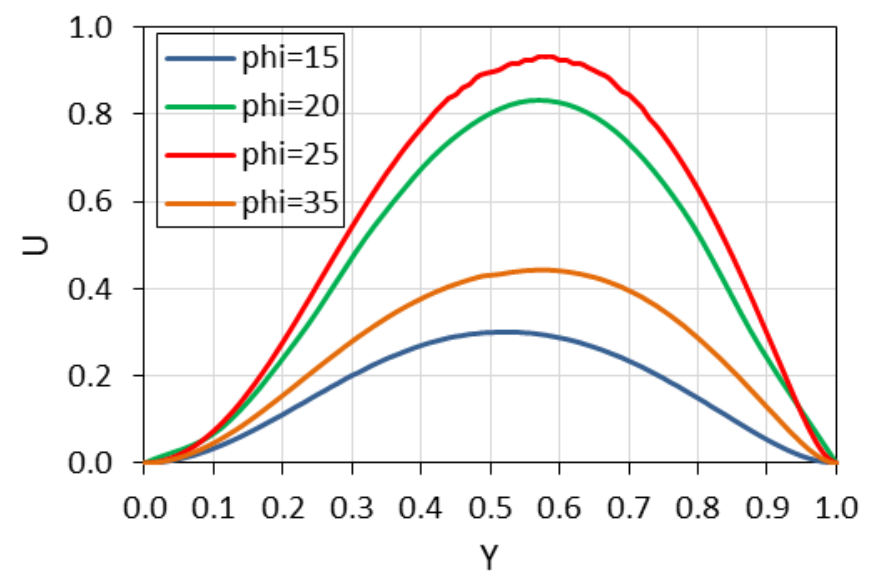

Fig. 5. Velocity along the centerline at $\mathrm{X}=0.5 \mathrm{~L}$ of the roof pitch angles.

Velocity variation along the centerline at $\mathrm{X}=0.5 \mathrm{~L}$ of all the enclosures is presented in Fig. 5 . A profile shows the strength of the plume between two central counter-rotating cells. In an enclosure, the profile forms a parabolic shape. It describes the velocity of the hot air as it accelerates upward to a maximum velocity about the mid-height. Thereafter, it loses its strength as it pushes through the cold air on the upper area. The value of the maximum dimensionless velocity, $U_{\max }$, for each enclosure increases with roof pitch except that of the $35^{\circ}$ that suddenly drops to 0.44 . This is because the two cells within that roof pitch enclosure contain mainly very cold fluid. The profile could be used to forecast of the velocity value along the vertical midsection of a similar roof.

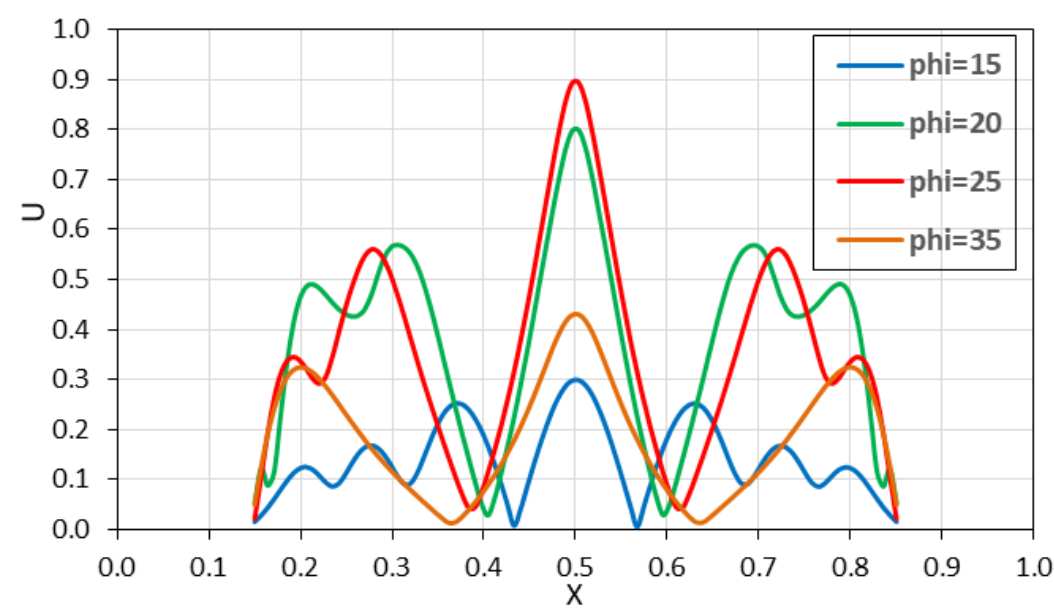

Fig. 6. Velocity along horizontal line at $\mathrm{Y}=0.5 \mathrm{H}$ of the roof pitch enclosures.

The variation of the velocity across the midheight of each of the enclosures is shown in Fig. 6. The variation depends on the parts of the cells that the horizontal line crosses. While all the three cells in the $15^{\circ}$ roof pitch are captured, only two of those in the $20^{\circ}$ and $25^{\circ}$ enclosures fall along the line. The peaks coincide with the point where adjacent cells meet while the troughs are at the centre of the cells. The span between adjacent peaks therefore connotes the diameter 
of a cell. The plot makes the prediction of a cell size and its strength at a point in the attic to be possible. This information is useful for a proper ventilation of the roof and for food crops drying.

\subsection{Temperature Field}

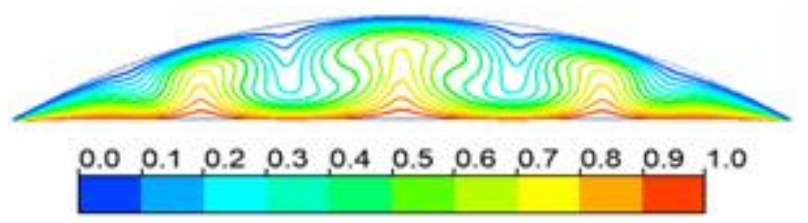

(a) $15^{\circ}$

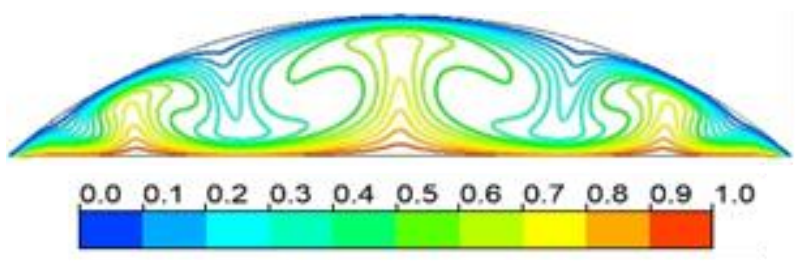

(b) $20^{\circ}$

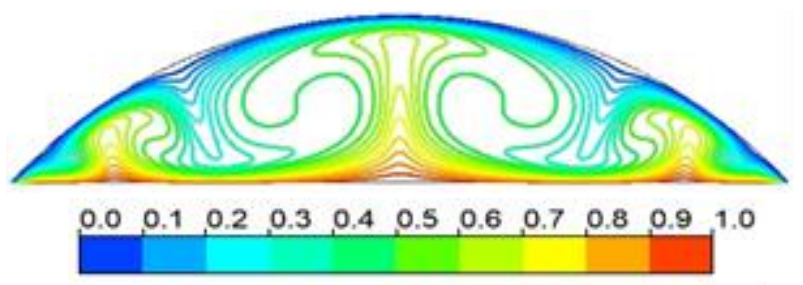

(c) $25^{\circ}$

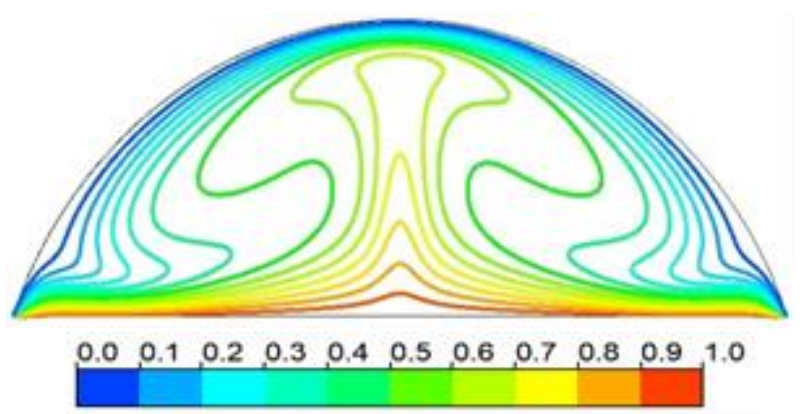

(d) $35^{\circ}$

Fig. 7. Temperature field within different roof pitch enclosures.

Fig. 7 indicates the contour plot of the isotherms within the enclosures. The pattern depicts rising hot plumes from the base wall and cold jets dropping from the parabolic wall in synchronous with the convection currents. Half of a plume and half of an adjacent jet make a cell. As the roof pitch increases, the plume at the centre becomes larger and the thermal 
boundary layers along the walls thicken. Near the corners, conduction dominates. This is as a result of the quenching effect the cold fluid flowing down the parabolic wall has on the heated air at the corners. The average temperature across the roof pitch enclosures reduces as the pitch angle increases because more volume of cold fluid has to be heated by the same length of the base wall.

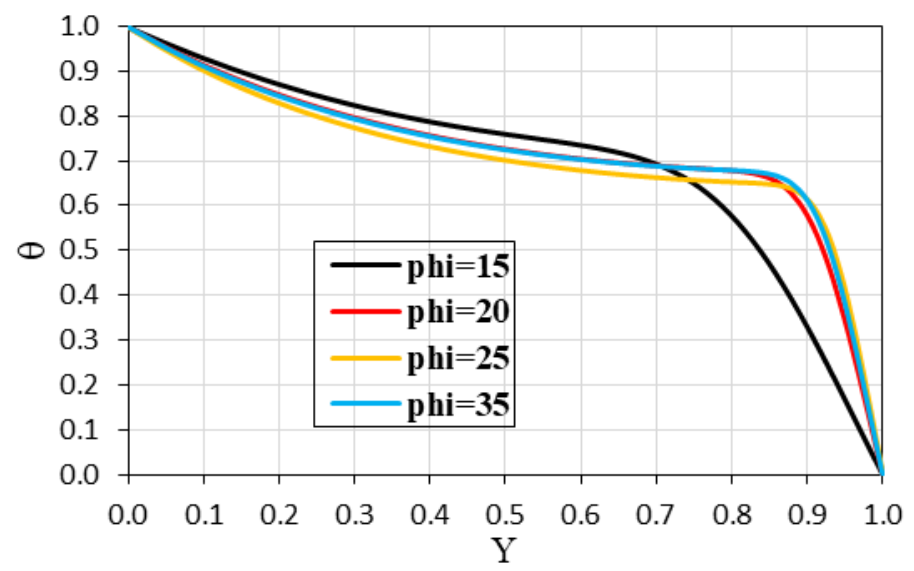

Fig. 8. Temperature along the centerline at $X=0.5 \mathrm{~L}$ of the roof pitch enclosures.

The temperature variation of air along the central plume at the centerline is shown in Fig. 8 . The plot shows that temperature reduces gradually upward from the base wall to the edge of the thermal boundary layer on the upper cold wall. Expectedly, there is a high temperature gradient within the layer.

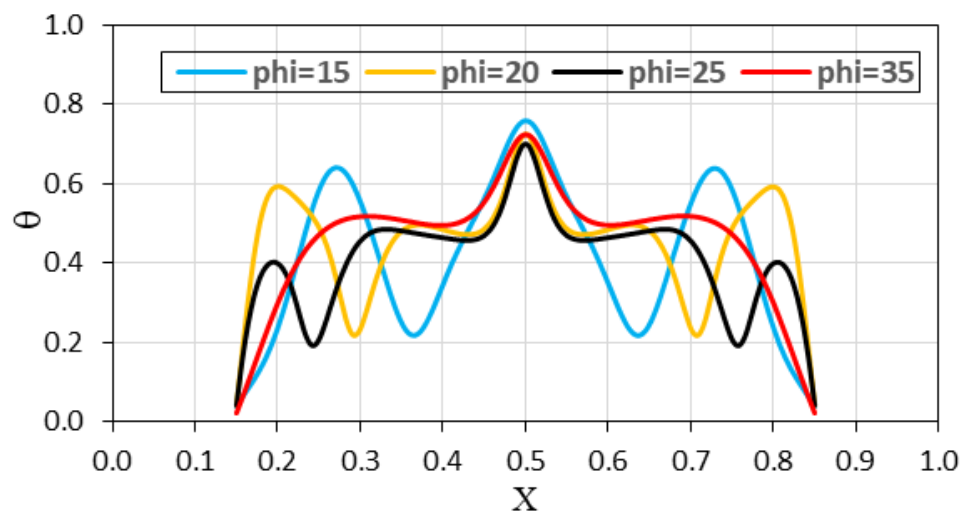

Fig. 9. Temperature along horizontal line at $\mathrm{Y}=0.5 \mathrm{H}$ of the roof pitch enclosures.

Fig. 9 shows the variation of the temperature along the midheight for all the enclosures. The pattern of the temperature profile is in consonant with the flow field. A peak coincides with the middle of a plume while the trough corresponds to the middle of a jet. Therefore, the diameter 
of a cell at a location is represented by the distance between adjacent peak and bottom at that location.

\subsection{Heat Transfer}

The rate of heat transfer within the roof pitch enclosures is reported using the Nusselt number variations as illustrated by the values of the local heat transfer coefficient, $h_{x}$, along the walls of each enclosure. The definition of the local Nusselt number adopted in this study is:

$$
N u_{x}=\frac{h_{x} L}{\lambda}
$$

The length, $L$, of the horizontal base wall is taken as the characteristic length to enable comparison of heat transfer data obtained for enclosures having the same base-length.

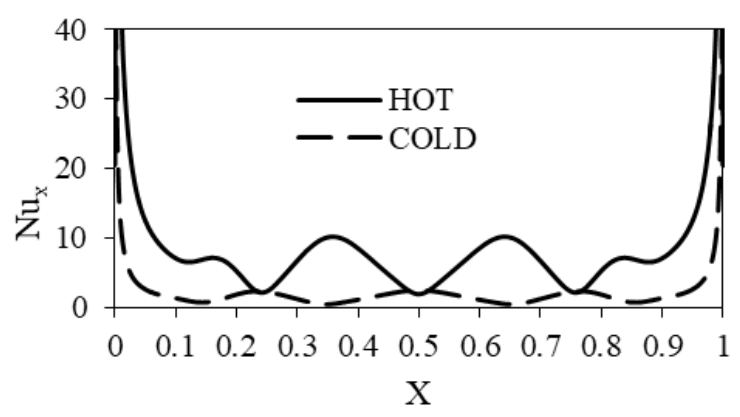

(a) $15^{\circ}$

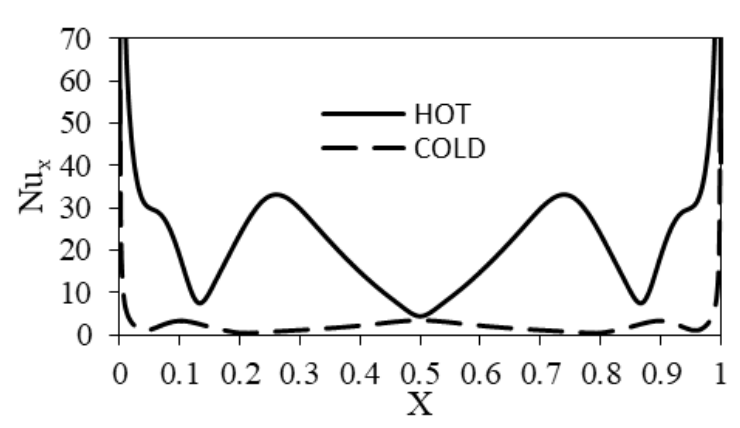

(c) $25^{\circ}$

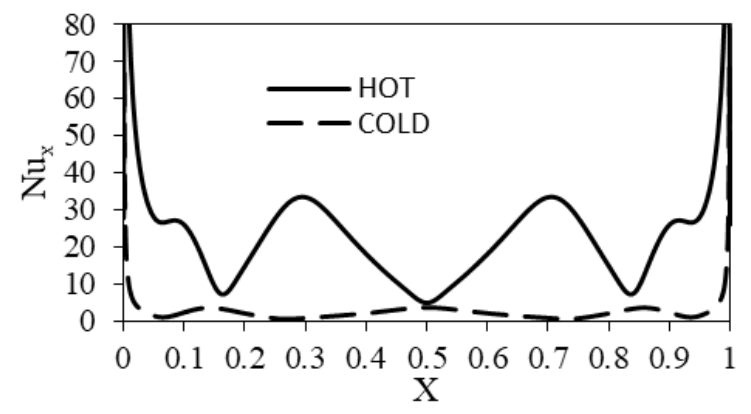

(b) $20^{\circ}$

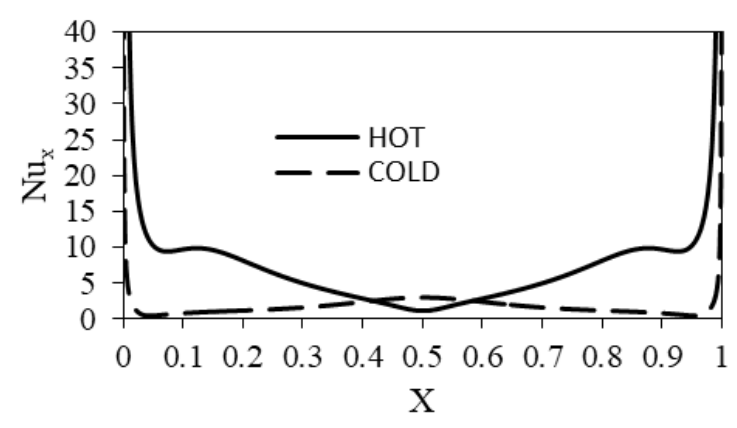

(d) $35^{\circ}$

Fig. 10. Local $N u$ plots for different roof pitch enclosures.

The heat transfer pattern along the hot and cold walls, shown in Fig.10, matches the flow of the plumes and jets from the walls. The heat transfer rate is high where the plumes splash on the cold parabolic wall and the jets drop on the hot base wall. The rate is low at points at which two counter-rotating vortices pull hot or cold air away from a wall. The gap between two peaks coincides with the diameter of a cell.

The wall mean Nusselt number is defined as: 


$$
\overline{N u}=\frac{\overline{\mathrm{h}} \mathrm{L}}{\lambda}
$$

where $\hbar$ is the mean heat transfer coefficient.

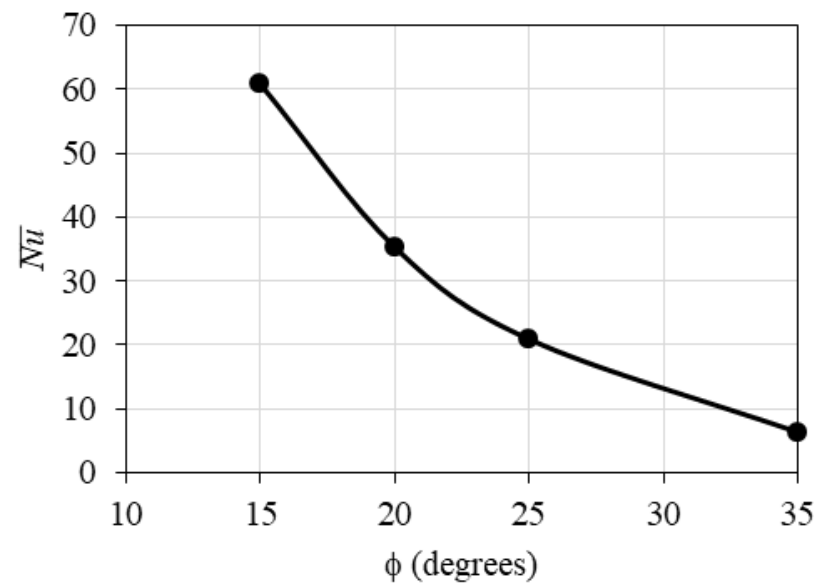

Fig. 11. Average Nusselt number of the hot base wall against roof pitch.

The relation between the average Nusselt number of the hot wall for each roof pitch is shown in Fig.11. The plot is negative-gradient quasi-linear. The $\overline{N u}$ value at $35^{\circ}$ roof pitch drops drastically to $10 \%$ of that for the $15^{\circ}$. This is attributed to the larger volume of air being heated by the same length of the hot wall. Similar trend of $\overline{N u}$ reduction as roof pitch angle increases is reported by Haese and Tuebner (2002) for triangular attic space heated from below.

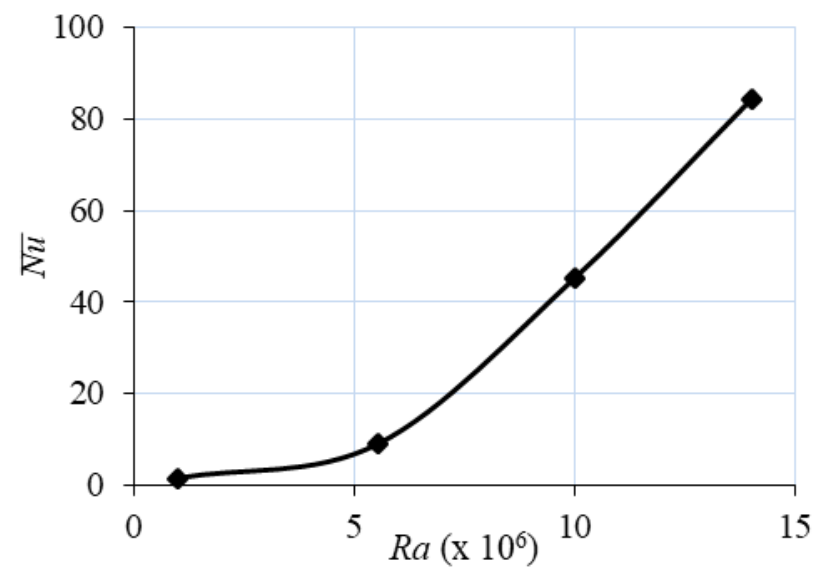

Fig. 12. Mean Nusselt number of the hot basewall against Rayleigh number for $15^{\circ}$-roof pitch enclosure.

The variation of the mean Nusselt number $(\overline{\mathrm{Nu}})$ of the hot basewall with the Rayleigh number $(R a)$ is shown in Fig. 12 for the $15^{\circ}$ roof pitch enclosure. The $R a$ at $5 \times 10^{6}$ appears to be a critical value in which the value of the $\overline{N u}$ increases sharply after it. At $R a$ value of $5.5 \times 10^{6}$, the $\overline{N u}$ value is 8.9. Yesiloz and Aydin (2011), in their experimental study of natural convection 
in inclined quadrantal cavity, reported an $\overline{N u}$ value of 8.4 for $R a$ at $5 \times 10^{6}$. Also, Talabi and Nwabuko (1993) reported 9.0 at the same $R a$ value.

The implications of the results obtained in this study are many. In winter time, the roof pitch should be high if the heat loss into the attic is to be minimized. For roofs with low pitch however, appropriate quality and thickness of insulation should be installed on the ceiling. On the other hand, in the communities where drying of agricultural crops in roofs are still being practiced, the roof pitch angle should be low for efficient performance.

\section{CONCLUSIONS}

Laminar natural convective heat transfer of air in enclosures of parabolic shape heated from the bottom wall without the usual configuration symmetry assumption has been studied. In all the enclosures, the flowfield is characterized by multiple counter-rotating vortices arranged quasisymmetrically. There are reduction in the size and intensity of the on the cells from the center to the bottom corners. The cells formed change structure from being rectangular at the periphery to circular at the core indicating that the shapes of the cells are moulded by the bounding curved and flat surfaces of the enclosure. At the centre of each enclosure, a widening thermal plume exists. The thermal boundary layers along the walls thicken as the roof pitch increases. The heat transfer pattern matches the flow of the plumes and jets from the walls. The Rayleigh number becomes critical at $5 \times 10^{6}$ as the heat transfer rate increases sharply after it.

\section{REFERENCES}

Aich, W., Hajri, I. and Omri, A. (2011) 'Numerical analysis of natural convection in a prismatic enclosure', Journal of Thermal Science, 15(2), 437-446.

Amrani, A., Dihmani, N., Amraqui, S., and Mezrhab, A., (2017) 'Analysis of combined natural convection and thermal radiation heat transfer in a triangular shaped roof for hot climates', Journal of Materials and Environmental Sciences, 8(8), 3013-3027.

Asan, H. and Namli, L. (2000) 'Laminar natural convection in a pitched roof of triangular crosssection: summer day boundary conditions', Journal of Energy and Building, 33, 69-73.

Basak, T., Anandalakshmi, R. and Biswal, P. (2013) 'Analysis of convective heat flow visualization within porous right angled triangular enclosures with a concave/convex hypotenuse', Numerical Heat Transfer, Part A: Applications, 64 (8), 621-647.

Colliers, J., Degroote, J., Mollaert, M., and De Laet, L. (2020) 'Mean pressure coefficient distributions over hyperbolic paraboloid roof and canopy structures with different shape parameters in a uniform flow with very small turbulence', Engineering Structures, 205, 110043 
Das, D., Roy, M. and Basak, T. (2017) 'Studies on natural convection within enclosures of various (non- square) shapes- A review', International Journal of Heat and Mass Transfer, 126, 356-406.

Das, S. and Morsi, Y. (2002) 'Natural convection inside dome shaped enclosures', International Journal of Numerical Methods for Heat and Fluid Flow, 12(2), 126-141.

Elnokaly, A., Ayoub, M. and Elseragy, A. (2019) 'Parametric investigation of traditional vaulted roofs in hot-arid climates', Renewable Energy, 138, 250-262.

Faghih, A. and Bahador, M.N. (2011) 'Thermal performance evaluation of domed roofs', Energy and Buildings, 43(6), 1254-1263.

Gray, D.D. and Giorgini, A. (1976) 'The validity of the boussinesq approximation for liquids and gases', International Journal of Heat and Mass Transfer, 19, 545-551.

Haghighi, A.P., Golshaahi,S.S. and Abdinejad, M. (2015) 'A study of vaulted roof assisted evaporative cooling channel for natural cooling of 1-floor buildings', Sustainable Cities and Society, 14, 89-98.

Holtzman, G.A., Hill, R.W. and Ball, K.S. (2000) 'Laminar natural convection in isosceles triangular enclosures heated from below and symmetrically cooled from above', Journal of Heat Transfer, 122(3), 485-491.

Kamiyo, O.M., Angeli, D., Barozzi, G.S., Collins, M.W., Olunloyo, V.O.S. and Talabi, S.O. (2010) 'A comprehensive review of natural convection in triangular enclosures', Journal of Applied Mechanics Review, 63, 060801, 13 pages.

Kamiyo, O.M., Angeli, D., Barozzi, G.S. and Collins, M.W. (2014) 'Natural convection in asymmetric triangular enclosures heated from below', Journal of Physics, 547, 1-10.

Mahmoudi, A., Mejri, I., Abbassi, M.A., and Omri, A., (2013) 'Numerical study of natural convection in an inclined triangular cavity for different thermal boundary conditions: application of the lattice Boltzmann method, Fluid Dynamic Material Process', 9, 353-388.

Mirabedin, S. (2016) 'CFD modeling of natural convection in right-angled triangular enclosures', International Journal of Heat Technology, 34(3), 503-506.

Moftakhari, A., Aghanajafi, C. and Ghazvin, A.M.C. (2017) 'A novel numerical approach for convective and radiative heat transfer analysis of fluid flow problem within triangular cavities using natural element method', Journal of Heat Transfer, 139 (8), 082002 (13 pages).

Moukalled, F. and Acharya, S. (2001) 'Natural convection in trapezoidal enclosure with offset baffles', Journal of Thermophysics, Heat and Mass Transfer, 5(5), 212-218.

Mustafa, A. W. (2011) 'Natural convection in parabolic enclosure heated from below', Modern Applied Science, 5(3), 213-220. 
Penot, F. and N'Dame, A. (1992) 'Successive bifurcations of natural convection in a vertical enclosure heated from the side', Heat Transfer: Proceedings of 3rd UK National Conference and First European Conference on Thermal Sciences, UK, 1, 507-513.

Raj, R., Pradyumna, K. C., Rakshith, B.R., Nithin, R.B. and Karthik, S.R. (2018) 'Combined natural convection and surface radiation inside vented triangular enclosure- an experimental study', International Conference on Research in Mechanical Engineering Sciences, 144, 04019 (8 pages).

Ridouane, E. H., Campo, A. and McGarry, M. (2005) 'Numerical computation of buoyant airflows confined to attic spaces under opposing hot and cold wall conditions', International Journal of Thermal Sciences. 44, 944-952.

Rizzo, F. and Riccardelli, F. (2017) 'Design pressure coefficients for circular and elliptical plan structures with hyperbolic paraboloid roof’, Engineering Structures, 139, 153-169.

Rizzo, F., Barbato, M. and Sepe, V. (2018) 'Peak factor statistics of wind effects for hyperbolic paraboloid roofs', Engineering Structures, 173, 313-330.

Runsheng, T., Meir, I.A. and Etzion, Y., (2003) 'An analysis of absorbed radiation by domed and vaulted roofs as compared with flats roofs', Journal of Energy and Buildings, 35, 539-548. Shen, X., Yang, Q., Li, L., Gao, Z. and Wang, T., (2020) 'Numerical approximation of the dynamic Koiter's model for the hyperbolic parabolic shell', Applied Numerical Mathematics, 150, 194-205.

Sieres, J., Campo A. and Martinez-Suarez, J.A. (2016) 'Natural convection air flow in vertical upright -angled triangular cavities under realistic thermal boundary conditions', Journal of Thermal Science, 20(5), 1407-1420.

Simoni, T. and Nordestgaard, P. M. (2017) 'Hyperbolic paraboloid shape shell structure: As roof for an outdoor music stage', Special Issue: Proceedings of Eurosteel, 1(2-3), 4486-4491.

Talabi, S. O. and Nwabuko, U. (1993) 'Numerical solution of natural convective heat transfer in parabolic enclosures', International Journal of Heat and Mass Transfer, 36(17), 4275 - 4281. Triveni, M.K., Sen D. and PanuaR.S. (2015) 'Natural convection in a partially heated triangular cavity with different configurations of cold walls', Journal of Science and Engineering, 40, 3285-3297.

Varol, Y., Koca, A. and Oztop, H.F. (2007) 'Natural convection heat transfer in Gambrel roofs', Journal of Building and Environment, 42, 1291-1297.

Yao, H., Xiao, M. and Aldridge, K. (1995) 'A numerical study of natural convection in a parallelogrammic enclosure', Proceedings of 9th International Conference on Numerical Methods in Thermal Problems, 9, 30-38. 
Yesiloz, G. and Aydin, O. (2011) 'Natural convection in an inclined quadrantal cavity heated and cooled on adjacent walls', Experimental Thermal and Fluid Science, 35, 1169-1176. 